\title{
Impact of the Digital Literacy Courses Taken by the Prospective Social Studies Teachers by Distance Learning on Digital Citizenship Skills
}

\author{
Mithat Aydın , Türkan Çelik ${ }^{\mathrm{b}}$ \\ ${ }^{a}$ Pamukkale University,Turkey,maydin@pau.edu.tr, https://orcid.org/0000-0002-2066-845X \\ ${ }^{b}$ Kilis 7 Aralık University, Turkey, turkancelik@kilis.edu.tr,https://orcid.org/0000-0001-8380-9419
}

\begin{abstract}
The purpose of this study is to determine the efficacy of the digital literacy course taught to undergraduates with the cooperation of the Council of Higher Education (CHE) and Anadolu University on the 'digital citizenship skills' of social sciences teachers. In this context, 30 prospective social sciences teachers who received digital literacy training participated in the study, which employed criterion sampling, a purposive sampling technique. The study followed a pretest and post-test uncontrolled quasi-experimental model. The digital literacy course process by distance learning covered eight weeks. At the beginning and the end of the digital literacy course, a 'digital citizenship' scale was applied to the prospective teachers. In research results, a significant positive difference was detected between the pre-test and post-test scores of prospective teachers obtained from the whole of the digital citizenship skills scale. Between pre-test and posttest scores of 'digital communication', 'digital ethics', and 'critical thinking' sub-dimensions of the digital citizenship scale, a significant difference was not detected. On the other hand, a positive significant difference was detected between scores from its digital skills, digital participation, digital rights and responsibilities, and digital commerce sub-dimensions. Similarly, between digital security points, which is another sub-dimension of the study, a significant difference was detected, though this difference was found to be negative. In this context, it is proposed that similar training should be made more common, more functional subjects in digital topics that teachers do not know should be the focus rather than those prospective teachers are expected to know, some changes regarding digital security must be implemented in institutions that teach the digital literacy course with distance learning and that these should enrich this subject further.
\end{abstract}

Keywords: social studies teacher candidates, digital literacy, distance learning, digital citizenship, digital citizenship skills.

\section{Introduction}

The wave of change experienced in every field recently also affects educational institutions with new digital technologies. Changes in the field of technology, rapid as if in a race against time, made changes in the teacher and student profile of our century inevitable. Indeed, students of our time who open their eyes to the world as digital natives made the command of digital technologies almost a necessity on part of teachers. Such that, to effectively lead their students in learning environments and to have the skills of the 21 st century, teachers must integrate new technologies into their field and become citizens with digital literacy skills. However, the efficacy of courses the teachers take during their university education when they gain expertise is important. It is evident that teachers, who are one of the important authorities in the education process, cannot be sufficient for digital-native students of today with information and skills of the past. Such that, information and technologies bequeathed from societies that undergo constant change and transformation from the past to our day have reached more advanced dimensions today and novel needs in daily life almost pushed individuals to a digital transformation process. Thus, people witness many technologies they used in the past to rapidly digitalize through the computer and internet technologies. Moreover, the generation called 'the $\mathrm{Z}$ generation' opened its eyes to the world as digital natives. Digital natives connect to the internet from different parts of the world and engage in activities within the digital ecosystem such as producing content in digital channels, sharing information, communicating, and defending their rights by organizing (Prensky, 2001). Such a situation caused different institutions in many societies to transfer to the digital world. Indeed, while digitalization used to be employed more in commercial mediums, now it is used intensely in fields such as health, transportation, marketing, management, and education too. Especially problems such as pandemics that have affected the world recently rendered the continuity of many daily-life routines through digital channels a necessity and made the healthy adaptation of individuals to the transformations of digitalizing institutions a need. Indeed, following the worldwide pandemic as a result of the COVID-19, an opportunity arose to continue the education process through virtual channels. This shows the importance and necessity of digital knowledge and skills for every citizen. Social sciences teachers, who have an important share in the raising of citizens that keep up with the digital 


\section{Impact of the Digital Literacy Courses Taken by the Prospective Social Studies Teachers by Distance Learning on Digital Citizenship Skill \\ Mithat Aydın, Türkan Çelik}

world, are expected to be aware of these latest novelties and developments and be competent in digital knowledge and skills. It is one of the requirements of digital citizenship that citizens raised in this context have an awareness of their responsibilities towards both their society and the whole world. Indeed, though digital citizenship, which requires the possession of many competencies, has been defined in many different ways, it calls attention to many definitions that emphasize common points. Thus, in the literature, digital citizenship has been defined as the skill to use technology in a socially safe, responsive, critical, and fruitful manner (Farmer, 2010; Karaduman, 2011); a process that prepares the individual to the digital society together with a method that instructs the individual about how he/she ought to use technological devices (Görmez, 2017); the ability of people in the process of using digital competencies to be self-critical, to be aware of ethical behaviour in the virtual environment, to be able to use technology without harming others while using the right to communication on the internet, and to embrace the right attitude in their shares on the virtual environment, and set an example for others (Çubukçu \& Bayzan, 2013); the skill to assume responsibility of attitudes and behaviour in the process of using technology (Mossberger et al., 2008); and to act in the virtual environment within the framework of ethical and universal rules and be aware of potential dangers (Aydın, 2015). Ribble (2011) approaches digital citizenship in nine dimensions. These dimensions are digital access, digital commerce, digital communication, digital literacy, digital ethics, digital law, digital rights and responsibilities, digital health and fitness, and digital security. Thus, citizens of the 21 st century turned towards developing themselves in more flexible learning environments with technology, one of the greatest yields of the new century (Uzun, 2019, p. 72). For this reason, to raise citizens that have 21 st-century skills and reach information rapidly, adapt to society and the world, and develop technology healthily, digital technologies should be included in social sciences courses as in all other courses (Yeşiltaş \& Sönmez, 2009). In this context, it is beneficial to investigate the direction of education programs that incorporate different competencies of digital literacy.

\subsection{Social Studies Education and Digital Literacy}

The concept of digital literacy has been defined as to use technology-supported media in reading and writing (Pilgrim \& Martinez, 2013) and the skill to read and interpret media (text, voice, images) and to evaluate and apply new information obtained through digital environments (Jones-Kavalier \& Flannigan, 2006). In the literature (Akkoyunlu \& Soylu, 2010; Eshet, 2002; Hague \& Payton, 2010), it is stated that individuals with digital literacy can use digital tools effectively and fruitfully in their daily lives, can reach and share information through digital tools, integrate information in different forms, can use digital tools more effectively and fruitfully than others around themselves, are aware of the sociocultural effects of the digital environments, and have skills to communicate and critically think with digital tools. The emphasis on and the functionality of digital literacy in the education systems of the 21 st century has been increasing with each passing day. Indeed, as elsewhere in the world, it is seen that one of the most notable subjects among eight headings of the Turkish Competencies Framework (TCF), part of our country's education curricula, is the heading of 'digital competency'. The competencies in the digital field, which should be emphasized in particular, are related to media, internet, and social networks which have become integral parts of the individual in social life. Through the training given in the context of the programme, it is observed that the basic skills such as access to information; the use of computers for the evaluation, storage, production, presentation, and exchange of information; participation in common networks via the internet; and communication are expected to integrate with digital competence skills. This is also supported in the specific objectives of the Social Sciences Course curricula, which play an important role in raising active citizens of the society. Among 27 skills aimed to be taught within the Social Sciences Course, 'perceiving change and continuity', 'digital literacy', and 'media literacy' also emphasize the importance of this issue. In the description of one of the learning areas that constitute the backbone of the program, 'science, technology, and society', the importance of helping students gain an innovative and critical thinking perspective in social studies courses for the development of science and technology are emphasized. In addition, students are expected to gain the ability to use technology consciously by seeing examples of the effects of science and technology on social life in this learning area. Therefore, it is important that teachers enrich their courses with activities that will feed digital competence during the process of teaching social studies. Moreover, organizing technology-assisted learning environments is an indicator of the fact that the teacher of the 21 st century has become technologically competent and productive (Orhan Göksün \& Kurt, 2018). However, the existence of some problems that prevent the use of technology in the education process stands out in the literature. Findings of studies based on curricula (Aydemir, 2019; Elçi \& Sar1, 2016; Görmez, 2017; Kara \& Atasoy, 2019; Turan \& Karasu Avc1, 2018), teachers (Arcagök, 2020; Görmez, 2017), students (Elçi, 2015; Erdoğan \& Tonga, 2020; Karaduman, 2011; Karaduman \& Öztürk, 2014; Koçoğlu et al., 2020; Öztürk, 2015; Som Vural \& Kurt 2018; Ünal, 2017), and prospective teachers (Aslan, 2016; Bakır, 2016; Çakmak \& Aslan, 2018; Dere \& Yavuzay, 2019; Görmez, 2016; Kaya \& Kaya, 2014; Kocadağ, 2012; Sakall1, 2015; Sakallı \& Çiftçi 2016) show that with positive developments in the education process, occasionally, 
problems pertaining to the use of technology also persist. In addition to studies on different fields, according to the findings of Yavuzay's (2019) study, which investigates digital citizenship indications of prospective social sciences teachers, a significant difference between their scores on the digital citizenship scale and their duration of internet use was not detected, but a significant difference was found between groups in their frequency of using e-government. Similarly, in Çakmak and Aslan's study (2018), where the researchers descriptively analysed prospective social sciences teachers' perceptions of digital citizenship and its sub-dimensions, they documented a significant positive difference between the variable of the time spent online and attitudes towards digital citizenship in prospective teachers. As the time prospective teachers spent online increased, their attitudes towards digital citizenship were affected positively. Moreover, participants defined digital citizens as innovative individuals who use computers and the internet very well and who adapt to technology. In the suggestions of the study, considering the responsibility of social sciences teachers in teaching students their rights and freedoms, the researchers stated that the teaching of digital citizenship ought to be integrated to both courses of social sciences teaching departments in universities and to social sciences courses in the primary and secondary school curricula. Thus, it is known that in raising the citizens of the digital era healthily, social sciences teachers have an undeniable role. In this context, it is necessary that prospective social sciences teachers themselves are digital literate citizens in the first place. When the relevant literature is reviewed, there were not any studies considering the effects of the training that prospective social sciences teachers receive by taking the digital literacy course virtually through distance learning on digital citizenship and its sub-dimensions. In this respect, it is thought that this study will shed light on this issue from a different perspective.

\section{Purpose of the Research}

Pandemics that we have been experiencing recently such as the COVID-19 show the importance of both digital citizenship and virtual and distance education. This study considers the efficacy of the digital literacy course, which began as part of the 'Digital Transformation in Higher Education Project' in November 2018, at eight universities with the cooperation of the Council of Higher Education (CHE) and Anadolu University and continued with eight additional universities, reaching a total of 16 pilot universities as of July 2019 and then offered to undergraduates from 2019 to 2020 spring term, in social sciences teachers. The purpose of the study is to determine the difference made by the education received by prospective social sciences teachers who took the Digital Literacy Course online with distance learning on the pre-test and post-test scores of the 'digital citizenship' scale and its sub-dimensions. In this context, the study sought to answer the following questions:

1) What is the difference between the pre-test and post-test digital literacy scores of prospective teachers?

2) What is the difference between the pre-test and post-test scores of prospective teachers regarding the communication dimension?

3) What is the difference between the pre-test and post-test scores of prospective teachers regarding the rights and responsibilities dimension?

4) What is the difference between the pre-test and post-test scores of prospective teachers regarding the critical thinking dimension?

5) What is the difference between the pre-test and post-test scores of prospective teachers regarding the participation dimension?

6) What is the difference between the pre-test and post-test scores of prospective teachers regarding the security dimension?

7) What is the difference between the pre-test and post-test scores of prospective teachers regarding the digital skills dimension?

8) What is the difference between the pre-test and post-test scores of prospective teachers regarding the ethics dimension?

\section{Method}

This research, which adopts quantitative research methods, employs a pre-test and post-test uncontrolled model. As part of the study, a 'digital citizenship' scale was applied to second-grade prospective social sciences teachers that took the digital literacy course for the first time with distance learning at the beginning of their training. After they received an eight-week-long digital literacy training, the 'digital citizenship' scale was once more applied to the prospective social sciences teachers, and the difference caused by the received training in prospective teachers' digital citizenship skills was examined. The important issue here is that once experimental procedures are completed, the same group is subjected to 
the same test and the difference between pre-test and post-test is examined (Kaptan, 1995; Sönmez and Alacapınar, 2013). The symbol of the model is presented in Table 1.

Table 1: Uncontrolled pre-test and post-test design.

\begin{tabular}{llll}
\hline Group & Pre-test & Procedure & Post-test \\
\hline G & S1 & $\mathbf{X}$ & S2 \\
& & & \\
\hline Participant & The application of the & Digital literacy training of eight & The application of \\
group & digital citizenship scale & weeks with distance learning & the digital \\
& as pre-test & & citizenship scale as \\
& & & post-test
\end{tabular}

\subsection{Participants}

As the study group of this research, prospective social sciences teachers that took the digital literacy course with distance learning were chosen. In this context, the sample of this study exemplifies the criterion sampling technique, which is a purposive sampling technique. Indeed, participants were chosen with criterion sampling, one of the purposive sampling techniques, defined as the choice of situations rich in offering in-depth information within the context of the study's purpose (Büyüköztürk et al., 2013). The criteria determined for this study and expected from the chosen group, chosen with the help of criterion sampling that filters conditions, situations, and objects necessary for a study (Büyüköztürk et al., 2013), are as follows: taking digital literacy course with distance learning, being a second-grade prospective social sciences teacher, participating in the eight-week-long digital literacy training sessions and volunteering for the research. A total of 30 prospective social sciences teachers voluntarily participated in the study. Twenty of the participants were female, whereas 10 were male. Also, all (30) participants defined themselves as active citizens and as fulfilling their citizenship rights and responsibilities in a personal information questionnaire collected from the participants. In line with the criteria stated above, the demographic data obtained from the participant prospective teachers are presented in Table 2.

Table 2. Demographic data of the participants

\begin{tabular}{|c|c|c|c|c|c|c|c|c|c|}
\hline Gender & f & $\begin{array}{l}\text { Environment in } \\
\text { which s/he grew }\end{array}$ & $\mathbf{F}$ & $\begin{array}{l}\text { Father's } \\
\text { education }\end{array}$ & $\mathbf{F}$ & $\begin{array}{l}\text { Mother's } \\
\text { education }\end{array}$ & f & $\begin{array}{l}\text { Daily } \\
\text { internet } \\
\text { usage }\end{array}$ & f \\
\hline Female & 20 & Village & 5 & Primary school & 12 & Primary school & 13 & $1-3 h$ & 9 \\
\hline Male & 10 & District & 11 & $\begin{array}{l}\text { Secondary } \\
\text { education }\end{array}$ & 14 & $\begin{array}{l}\text { Secondary } \\
\text { education }\end{array}$ & 10 & $3-5 \mathrm{~h}$ & $\begin{array}{l}1 \\
6\end{array}$ \\
\hline \multirow[t]{2}{*}{ Total } & 30 & Province & 4 & Higher education & 2 & Higher education & 1 & $\begin{array}{l}5 \mathrm{~h} \text { and } \\
\text { above }\end{array}$ & 5 \\
\hline & & Metropolis & 10 & Other & 2 & Other & $\begin{array}{l}6 \\
\mathrm{~h}\end{array}$ & & \\
\hline
\end{tabular}




\section{Impact of the Digital Literacy Courses Taken by the Prospective Social Studies Teachers by Distance Learning on \\ Digital Citizenship Skill \\ Mithat Aydın, Türkan Çelik}

\subsection{Experimental procedures}

The Digital Literacy Course that undergraduates take with distance learning as part of the 'Digital Transformation in Higher Education Project' conducted with the cooperation of the Council of Higher Education (CHE) and Anadolu University is offered as $2 \mathrm{~h} /$ week. A total training of eight weeks is offered to the students, which has the following headings (see Table 3).

Table 3. Total training of eight weeks is offered to the students

\begin{tabular}{|c|c|}
\hline Process & Transactions \\
\hline $\begin{array}{l}\text { The first week: Internet, } \\
\text { Web Browsers, and E- } \\
\text { Government }\end{array}$ & $\begin{array}{l}\text { This week in distance learning, prospective teachers received information about the development process } \\
\text { of the internet, its basic concepts, a comparison of web browsers, and the search engines. Also, under the } \\
\text { heading of 'e-government', prospective teachers were informed about how they can use the e-government } \\
\text { portal. }\end{array}$ \\
\hline $\begin{array}{l}\text { The second week: } \\
\text { Portable Technologies: }\end{array}$ & $\begin{array}{l}\text { As part of this week's training, the course introduced portable technologies such as tablets and mobile } \\
\text { phones and their characteristics to prospective teachers. Moreover, services provided with these } \\
\text { technologies and service protocols were considered in detail. }\end{array}$ \\
\hline $\begin{array}{l}\text { The third week: Social } \\
\text { Networks }\end{array}$ & $\begin{array}{l}\text { This week, the appearance of Web } 2.0 \text { technologies and how they differ from other web technologies were } \\
\text { considered. Also, social networks based on Web } 2.0 \text { technologies and their variants were discussed. } \\
\text { Sharing information regarding the characteristics of the most used social networks in recent times and } \\
\text { their effects on society, the course emphasized the importance of media literacy regarding the conscious } \\
\text { use of social networks in this context. }\end{array}$ \\
\hline $\begin{array}{l}\text { The fourth week: } \\
\text { Development } \quad \text { of } \\
\text { Society and } \\
\text { Technology }\end{array}$ & $\begin{array}{l}\text { As part of this week's training, lifestyles of people and technologies they used in their lives in hunter, } \\
\text { gatherer, agricultural, industrial, and information societies were considered first. Human-computer } \\
\text { interactions, philosophy of technology, and the behaviour of humans during the process of socializing with } \\
\text { social sharing networks were examined. }\end{array}$ \\
\hline $\begin{array}{l}\text { The fifth week: Ethics } \\
\text { in Digital Life }\end{array}$ & $\begin{array}{l}\text { This week, participants learned about the importance and areas of use of concepts such as scientific } \\
\text { ethics, informatics, internet law, and approaches and theories of ethics. In this context, types of licenses } \\
\text { used on the internet and their ethical use was considered. Also, the ethical rules of the commonly used } \\
\text { social networks were emphasized. }\end{array}$ \\
\hline $\begin{array}{l}\text { The sixth week: } \\
\text { Lifelong Learning }\end{array}$ & $\begin{array}{l}\text { Discerning differences between lifelong learning and traditional learning as well as related concepts were } \\
\text { considered. Basic principles and strategies of lifelong learning were considered and their characteristics } \\
\text { were emphasized. Moreover, the participants became aware of the basic characteristics of communal } \\
\text { Open Online Courses used in lifelong learning and their differences to traditional learning. }\end{array}$ \\
\hline
\end{tabular}




\section{Impact of the Digital Literacy Courses Taken by the Prospective Social Studies Teachers by Distance Learning on \\ Digital Citizenship Skill \\ Mithat Aydın, Türkan Çelik}

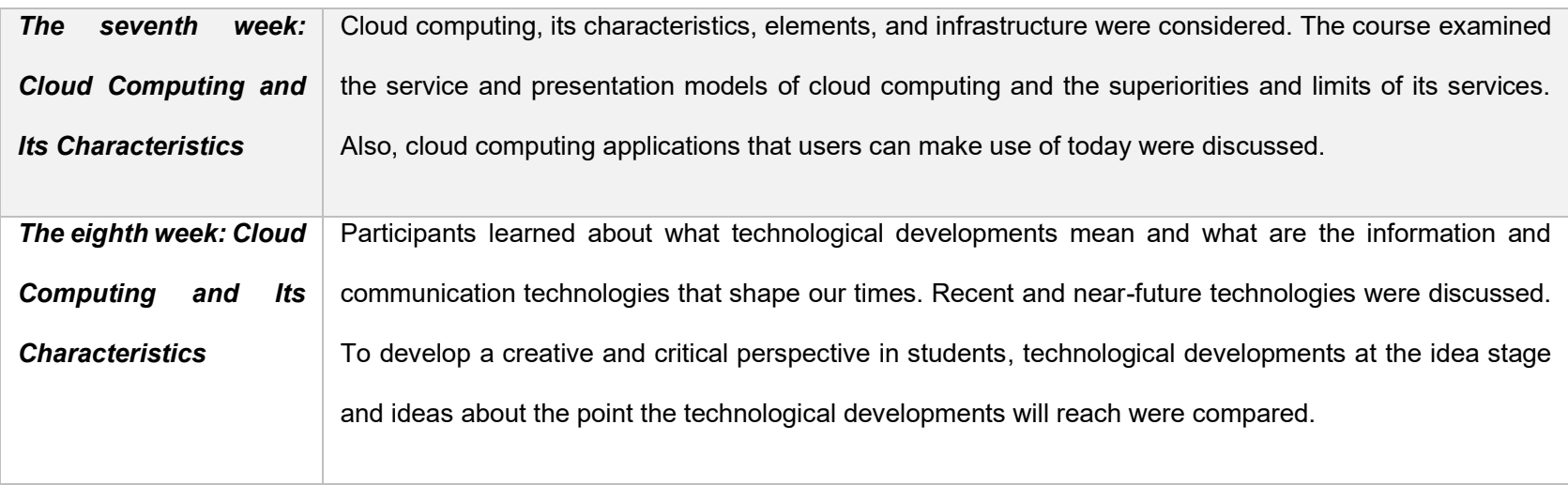

\subsection{Data Collection Tool}

To identify the difference on digital citizenship skills that the Digital Literacy Course causes, which prospective social sciences teachers took with distance learning, the study used the 'Digital Citizenship Scale' developed by Kuş et al. (2017). The highest score is 245 , whereas the lowest score is 49 obtained from this five-point Likert scale. A low score received by the participants in digital citizenship skills shows that their knowledge and skills in this area decreased, whereas the high score they receive shows that their digital citizenship knowledge and skills are at a high level. The scale consists of a total of eight factors and 49 items. As a result of the analyses conducted, it was found that the scale was reliable and valid. It was documented that its Kaiser-Mayer-Olkin (KMO) test value was 0.82 and its Cronbach's alpha reliability coefficient had the desired properties. The dimension names, number of items, and Cronbach's alpha reliability coefficient of the scale, composed of eight dimensions, are as follows: the communication dimension has six items and a reliability coefficient of 0.81 ; the rights and responsibilities dimension has nine items and a reliability coefficient of 0.80 ; the critical thinking dimension has seven items and a reliability coefficient of 0.78 ; the participation dimension has five items and a reliability coefficient of 0.73 ; the security dimension has six items and a reliability coefficient of 0.81 ; the digital skills dimension has five items and a reliability coefficient of 0.74 ; the ethics dimension has four items and a reliability coefficient of 0.79 ; and the commerce dimension has seven items and a reliability coefficient of 0.82 . The reliability coefficiencies obtained for each dimension in this research fall between 0.79 and 0.85 . Hence, in this scale prepared as a Likert-type scale, the score intervals determined based on the arithmetic mean are as follows: 1-1.80 interval 'I strongly disagree', 1.81-2.60 interval 'I disagree', 2.61-3.40 interval 'I somewhat agree', 3.41-4.20 interval 'I agree', and 4.21-5 interval 'I strongly agree'.

\subsection{Data Analysis}

Data obtained from 30 prospective teachers at the beginning and at the end of the digital literacy training with distance learning were analysed with the SPSS 22.0 software. To determine which ones of the parametric or non-parametric tests were to be used, a normality test was conducted first. As the sample size is smaller (30) than 50, the Shapiro-Wilk test was used. Had the number of participants been 50 or more, it would have been necessary to base the study on the results of the Kolmogorov-Smirnov test. As the results of the Shapiro-Wilk test used in this study indicated that the data displayed normal distribution, in the analyses, a paired samples t-test, which is a parametric test for one sample group was used. The tabulation of the data was based on the arithmetic mean $(\overline{\mathrm{X}})$, standard deviation $(\mathrm{Sx})$, $\mathrm{t}$ value $(\mathrm{t})$, degrees of freedom (df), and significance values $(\mathrm{P})$ of the data. 


\section{Impact of the Digital Literacy Courses Taken by the Prospective Social Studies Teachers by Distance Learning on \\ Digital Citizenship Skill \\ Mithat Aydın, Türkan Çelik}

\section{Findings}

To test whether the data displayed normal distribution, pre-test and post-test total scores and the differences between total scores of each dimension were calculated separately. The normality test was performed based on this difference.

Table 4. Table of Shapiro-Wilk test results

\begin{tabular}{lllll}
\hline & Arithmetic mean & Skewness value & Kurtosis value & $(\mathrm{P})$ \\
\hline Pre-test and post- & 12.5667 & -.195 & -1.011 &. $\mathbf{4 0 3}$ \\
test total & & & & \\
\hline Factor 1 & -1.7000 & .541 & .240 &. $\mathbf{1 0 3}$ \\
Factor 2 & 3.7333 & -.029 & -1.040 &. $\mathbf{2 7 6}$ \\
Factor 3 & .4333 & -.490 & -.131 &. $\mathbf{2 0 5}$ \\
Factor 4 & 5.7667 & .224 & -.625 &. $\mathbf{4 6 6}$ \\
Factor 5 & -3.3000 & .318 & .641 &. $\mathbf{4 9 4}$ \\
Factor 6 & 6.5333 & -1.100 & 2.217 &. $\mathbf{2 0 0}$ \\
Factor 7 & 1.1000 & .446 & -.023 &. $\mathbf{5 1 2}$ \\
Factor 8 & 9.0000 & .143 & .140 &. $\mathbf{9 5 3}$ \\
\hline
\end{tabular}

As seen from Table 4, according to the Shapiro-Wilk results on which the analysis conducted on the basis of the differences of pre-test and post-test score totals is based, the overall data shows a normal distribution. The scale used in the study consists of eight sub-dimensions. To determine the test to be applied in each dimension, first the differences of pre-test and post-test score sums of the dimensions were obtained and separately controlled to see whether they displayed normal distribution. As is visible also on Table 2, all dimensions (Factor 1: .403; Factor 2: .103; Factor 3: .205; Factor 4: .466; Factor 5: .494; Factor 6: .200; Factor 7: .512; Factor 8: .953) had normal distribution (P $>0.05)$. Based on these results, it was decided to conduct the analyses of the study with parametric tests.

\subsection{What is the difference between the pre-test and post-test digital literacy scores of prospective teachers?}

Findings on the first sub-problem of this research on the difference the digital literacy training they received with distance learning caused by prospective social sciences teachers' digital citizenship skills are given in Table 5 .

Table 5. Pre-test and post-test score differences of the participants

\begin{tabular}{lllllll}
\hline & $\mathbf{N}$ & $\overline{\mathbf{X}}$ & $\mathbf{S x}$ & $\mathbf{T}$ & $\mathbf{D f}$ & $\mathbf{P}$ \\
\hline Pre-test & 30 & 130.73 & 38.707 & $\overline{\mathbf{X}}$ & & \\
total & & & & & \\
Post-test & 30 & 143.30 & 15.272 & & \\
total & & & & & $\mathbf{0 2 4}$ \\
Post-test & 30 & -12.56667 & 28.89301 & -2.382 & 29 & \\
total - pre- & & & & & \\
test total & & & & & \\
\hline
\end{tabular}

$\mathrm{P}<0.05$. 


\section{Impact of the Digital Literacy Courses Taken by the Prospective Social Studies Teachers by Distance Learning on \\ Digital Citizenship Skill \\ Mithat Aydın, Türkan Çelik}

As is seen on Table 5, the digital literacy course affected the digital literacy skills of the prospective teachers that took the course with distance learning. It is observed that this effect is significant $(\mathrm{P}<0.05 ; 0.02)$ and positive. Indeed, while the arithmetic mean of the scores participants received from the digital citizenship scale in the pre-test was 24.4333 , it is seen that the average score in the post-test rose to 28.1667 . In this case, we can state that training on digital literacy has positive effects.

\subsection{What is the difference between the pre-test and post-test scores of prospective teachers regarding the}

communication dimension?

The findings on how the digital literacy course taken by the prospective social studies teachers through distance education affected the communication dimension from their digital citizenship skills is presented in Table 6.

Table 6. Pre-test and post-test score differences in the communication dimension

\begin{tabular}{lllllll}
\hline & $\mathrm{N}$ & $\overline{\mathrm{X}}$ & $\mathrm{Sx}$ & $\mathrm{t}$ & $\mathrm{df}$ & $\mathrm{P}$ \\
\hline Pre-test total & 30 & 14.6000 & 5.75715 & & \\
Post-test & 30 & 12.9000 & 4.71498 & & \\
total & & & & & \\
Post-test & 30 & 1.70000 & 7.93573 & 1.173 & 29 & .250 \\
total - pre- & & & & & \\
test total & & & & & \\
\hline
\end{tabular}

$\mathrm{P}>0.05$.

It is observed that the digital education that prospective teachers received with distance learning did not create a significant difference between the digital communication scores, a sub-dimension of digital citizenship. This finding gives rise to the possibility that prospective teachers had prior experience of digital communication before the education they received as part of the experimental procedures and may have developed skills in this field beforehand.

\subsection{What is the difference between the pre-test and post-test scores of prospective teachers regarding the rights and}

responsibilities dimension?

The findings on how the digital literacy course taken by the prospective social studies teachers through distance education affected the dimension of digital rights and responsibilities, a digital citizenship skill, are presented in Table 7.

Table 7. Pre-test and post-test score differences in the rights and responsibilities dimension

\begin{tabular}{|c|c|c|c|c|c|c|}
\hline & $\mathrm{N}$ & $\bar{X}$ & Sx & $\mathrm{t}$ & $\mathrm{df}$ & $P$ \\
\hline $\begin{array}{l}\text { Pre-test } \\
\text { total }\end{array}$ & 30 & 24.4333 & 8.67292 & & & \\
\hline $\begin{array}{l}\text { Post-test } \\
\text { total }\end{array}$ & 30 & 28.1667 & 5.38250 & & & \\
\hline $\begin{array}{l}\text { Post-test } \\
\text { total - pre } \\
\text { test total }\end{array}$ & 30 & 3.73333 & 7.74122 & -2.641 & 29 & .013 \\
\hline
\end{tabular}


$\mathrm{P}<0.05$.

When Table 7 is examined, it is observed that the arithmetic mean of the initial digital rights and responsibilities scores ( $\bar{X}: 24.4333$ ), part of the digital citizenship scale applied to prospective social sciences teachers at the beginning of their digital literacy training, is significantly different $(\mathrm{P}<0.05 ; 0.01)$ from the arithmetic mean of the scores they received from the post-test ( $\overline{\mathrm{X}}: 28.1667)$. In this context, we can state that the training prospective social sciences teachers received positively differentiated their digital rights and responsibilities skills. It is observed that although they had knowledge of digital communication beforehand, their awareness of rights and responsibilities in these communication channels was low as witnessed by the pre-test scores. However, with the training they received, they developed an awareness of digital rights and responsibilities, as reflected by the post-test scores they received in the rights and responsibilities dimension of the digital citizenship scale.

\subsection{What is the difference between the pre-test and post-test scores of prospective teachers regarding the digital}

critical thinking dimension?

The findings on how the digital literacy course taken by the prospective social studies teachers through distance education affected the dimension of critical thinking, a digital citizenship skill, are presented in Table 8 .

Table 8. Pre-test and post-test score differences in the critical thinking dimension

\begin{tabular}{lllllll}
\hline & $\mathrm{N}$ & $\overline{\mathrm{X}}$ & $\mathrm{Sx}$ & $\mathrm{t}$ & $\mathrm{df}$ & $\mathrm{P}$ \\
\hline Pre-test total & 30 & 18.1333 & 5.41220 & & & \\
Post-test & 30 & 18.5667 & 3.63587 & & & \\
total & & & & & & \\
Post-test & 30 & -.43333 & 6.75524 & -.351 & 29 & \\
total - pre- & & & & & & \\
test total & & & & & & \\
\hline
\end{tabular}

$\mathrm{P}>0.05$.

A significant difference was not detected between the pre-test and post-test average scores of prospective social sciences teachers regarding the critical thinking dimension on the digital citizenship scale of the digital literacy course that they took with distance learning. While a significant increase was expected in the critical thinking skills scores of prospective teachers following their digital literacy training, there was not a significant $(\mathrm{P}>0.05 ; 0.72)$ finding between the pre-test and post-test score differences. This finding suggests that considering their department, prospective teachers taking other courses aimed at questioning, researching, logical reasoning, and establishing cause and effect relationships between phenomena might have an impact. In this context, this gives rise to the idea that before embarking on the digital literacy training, prospective teachers already had awareness of critical thinking skills.

\subsection{What is the difference between the pre-test and post-test scores of prospective teachers regarding the digital}

participation dimension?

The findings on how the digital literacy course taken by the prospective social studies teachers through distance education affected the dimension of digital participation are presented in Table 9.

Table 9. Pre-test and post-test score differences in the participation dimension

\begin{tabular}{lllllll}
\hline $\mathrm{N}$ & $\bar{X}$ & $\mathrm{Sx}$ & $\mathrm{T}$ & $\mathrm{df}$ & $\mathrm{P}$ &
\end{tabular}


Impact of the Digital Literacy Courses Taken by the Prospective Social Studies Teachers by Distance Learning on

Digital Citizenship Skill

Mithat Aydın, Türkan Çelik

\begin{tabular}{|c|c|c|c|c|c|c|}
\hline $\begin{array}{l}\text { Pre-test } \\
\text { total }\end{array}$ & 30 & 12.8000 & 4.26210 & & & \\
\hline $\begin{array}{l}\text { Post-test } \\
\text { total }\end{array}$ & 30 & 18.5667 & 3.46095 & & & \\
\hline $\begin{array}{l}\text { Post-test } \\
\text { total - pre- } \\
\text { test total }\end{array}$ & 30 & -5.76667 & 5.02191 & -6.290 & 29 & .000 \\
\hline
\end{tabular}

It is found that the average scores of prospective teachers in the 'digital participation' dimension on the digital citizenship scale applied to them before their digital literacy training was significantly $(\mathrm{P}<0.05 ; 0.00)$ lower $(\overline{\mathrm{X}}: 12.8000)$ than their post-test average score $(\overline{\mathrm{X}}: 18.5667)$. This shows that the awareness of prospective teachers on the 'participation' skill in the digital media improved with the digital literacy course they took.

\subsection{What is the difference between the pre-test and post-test scores of prospective teachers regarding the digital}

security dimension?

Findings on how the digital security skill created a difference in prospective teachers' digital security scores as a result of the digital literacy course they took are presented in Table 10.

Table 10. Pre-test and post-test score differences in the security dimension

\begin{tabular}{lllllll}
\hline & $\mathrm{N}$ & $\mathrm{X}$ & $\mathrm{Sx}$ & $\mathrm{t}$ & $\mathrm{df}$ & $\mathrm{P}$ \\
\hline Pre-test total & 30 & 17.5000 & 5.39955 & & \\
Post-test & 30 & 14.2000 & 3.93394 & & & \\
total & & & & & \\
Post-test & 30 & 3.30000 & 6.36884 & 2.838 & 29 & \\
total - pre- & & & & & \\
test total & & & & & \\
\hline
\end{tabular}

$\mathrm{P}<0.05$.

It is important that people use digital channels with their minds at peace. When we examine how much the training prospective teachers received on this issue affected their digital security scores, it is found that their pre-test average score $(\overline{\mathrm{X}}: 17.5000)$ was significantly $(\mathrm{P}<0.05 ; 0.008)$ higher than their post-test average score $(\overline{\mathrm{X}}: 14.2000)$. In this context, it emerges that prospective teachers' digital security scores were higher before they received the digital literacy course. While a significant difference is thus detected in analyses of this sub-dimension of the study, it is observed that this difference is negative.

\subsection{What is the difference between the pre-test and post-test scores of prospective teachers regarding the digital skills}

dimension?

Findings on how the training prospective teachers received with the digital literacy course affected their digital skills dimension scores are presented in Table 11.

Table 11. Pre-test and post-test score differences in the digital skills dimension 
Impact of the Digital Literacy Courses Taken by the Prospective Social Studies Teachers by Distance Learning on

Digital Citizenship Skill

Mithat Aydın, Türkan Çelik

\begin{tabular}{lllllll}
\hline & $\mathrm{N}$ & $\overline{\mathrm{X}}$ & $\mathrm{Sx}$ & $\mathrm{t}$ & $\mathrm{df}$ & $\mathrm{P}$ \\
\hline Pre-test total & 30 & 13.9000 & 5.88012 & & \\
Post-test total & 30 & 20.4333 & 4.84009 & & & \\
Post-test total & 30 & 6.53333 & 6.97648 & -5.129 & 29 & .000 \\
- pre-test & & & & & \\
total & & & & & \\
\hline
\end{tabular}

$\mathrm{P}<0.05$.

When Table 11 is considered, it is found that the participants' digital skills dimension post-test average score $(\overline{\mathrm{X}}$ : $20.4333)$ significantly $(\mathrm{P}<0.05 ; 0.000)$ increased compared to their pre-test average score $(\overline{\mathrm{X}}: 13.9000)$. Prospective teachers acquiring digital skills, one of the 21 st-century skills, is important also for the students they will educate. Thus, it is important that they enhance their skills in this regard during their education in the faculties of education.

\subsection{What is the difference between the pre-test and post-test scores of prospective teachers regarding the ethics}

dimension?

Considering the etiquette to be followed in digital environments, digital ethics requires awareness of the legal responsibilities of an individual's overall behaviour and activities conducted in digital and virtual environments. It requires that the individual is aware of both his/her rights and responsibilities and those of others. In this context, it is necessary that prospective teachers themselves are sensitive to digital ethics and instill this awareness into their students they are to educate. Findings on the average score differences in the ethics dimension of the digital citizenship scale applied to prospective teachers as part of the digital literacy course are presented in Table 12.

Table 12. Pre-test and post-test score differences in the ethics dimension

\begin{tabular}{|c|c|c|c|c|c|c|}
\hline & $\mathrm{N}$ & $\bar{X}$ & Sx & $\mathrm{t}$ & $d f$ & $P$ \\
\hline $\begin{array}{l}\text { Pre-test } \\
\text { total }\end{array}$ & 30 & 9.9000 & 4.03733 & & & \\
\hline $\begin{array}{l}\text { Post-test } \\
\text { total }\end{array}$ & 30 & 11.0000 & 2.22834 & & & \\
\hline $\begin{array}{l}\text { Post-test } \\
\text { total - pre- } \\
\text { test total }\end{array}$ & 30 & -1.10000 & 4.94347 & -1.219 & 29 & .233 \\
\hline
\end{tabular}

$\mathrm{P}>0.05$.

When Table 10 is considered, it is determined that while prospective teachers' average post-test scores $(\overline{\mathrm{X}}: 11.0000)$ of the digital ethics dimension increased in comparison with their pre-test average score $(\overline{\mathrm{X}}: 9.9000)$, this increase was not a significant $(\mathrm{P}<0.05 ; 0.233)$ one.

\subsection{What is the difference between the pre-test and post-test scores of prospective teachers regarding the commerce}

dimension?

Nowadays, individuals can order and buy from their couch products from different cities, areas, or countries. In this context, in the digital environment, an intense commercial activity occurs. The skill to buy and sell properly and consciously in digital commerce, which makes commerce more comfortable for people, is important. In this context, prospective teachers are expected to be able to conduct commercial activities in digital environments. Findings on how 


\section{Impact of the Digital Literacy Courses Taken by the Prospective Social Studies Teachers by Distance Learning on \\ Digital Citizenship Skill \\ Mithat Aydın, Türkan Çelik}

the training given as part of the digital literacy course affected average scores of prospective teachers in the digital commerce dimension are presented in Table 13.

Table 13. Pre-test and post-test score differences in the commerce dimension

\begin{tabular}{lllllll}
\hline & $\mathrm{N}$ & $\overline{\mathrm{X}}$ & $\mathrm{Sx}$ & $\mathrm{t}$ & $\mathrm{df}$ & $\mathrm{P}$ \\
\hline Pre-test total & 30 & 19.4667 & 7.44976 & & & \\
Post-test total & 30 & 28.4667 & 4.27288 & & & \\
Post-test total & 30 & -9.00000 & 7.27300 & -6.778 & 29 & .000 \\
- pre-test & & & & & \\
total & & & & & \\
\end{tabular}

$\mathrm{P}<0.05$.

When Table 13 is examined, it is found that the participants' digital commerce dimension post-test average score $(\overline{\mathrm{X}}$ : $28.4667)$ significantly $(\mathrm{P}<0.05 ; 0.000)$ increased compared to their pre-test average score $(\overline{\mathrm{X}}: 19.4667)$.

\section{Discussion and Conclusion}

This research investigated how the Digital Literacy Course affected the scores prospective teachers took from the 'digital citizenship' scale. For this purpose, the study compared the pre-test and post-test scores of participants from the digital citizenship scale. The analysis results documented that there was a significant positive difference in the digital citizenship skills scores of prospective teachers that took the digital literacy course with distance learning. This result shows that the participants benefited from the digital literacy course that they took with distance learning. Other subproblems of the study concerned sub-dimensions of the digital citizenship scale of the digital literacy course, namely, communication, rights and responsibilities, critical thinking, participation, security, digital skills, ethics, and commerce. In the second sub-problem of the study, the difference between pre-test and post-test scores in the digital communication dimension was considered. In the results of the analysis, there was not a significant difference between the pre-test and post-test digital scores of the participants in the communication dimension. Considering that the youth use the internet tools intensely in their daily lives, that this result showed no difference can be regarded as normal. Indeed, it is known that in our century the internet and the internet tools are used intensely. Such that, according to the Global Digital report for 2020 , the number of internet users worldwide rose to 4.54 billion people, there are 3.80 billion social media users, over 5.19 billion people use mobile phones, and an average internet user spends $6 \mathrm{~h}$ and 43 min online (Fundalina, 2020). Considering also that worldwide, daily communication is continued intensely with the internet tools, we can state that the participants developed this skill well before taking the digital literacy course. Similarly, between the pre-test and posttest scores of digital ethics and critical thinking_skills, which are other sub-problems of the study, we did not detect a significant difference either. Considering the etiquette to be followed in digital environments, digital ethics requires awareness of the legal responsibilities of an individual's overall behaviour and activities conducted in digital and virtual environments. Hence, it requires that the individual is aware of both his/her rights and responsibilities and those of others. In this context, it is necessary that prospective teachers themselves are sensitive to digital ethics and instill this awareness into the students they are to educate. Likewise, in the analyses of critical thinking, which occupies a key position in the training of teachers, there was not any significant difference. Although we expected the digital literacy course to create a positive difference on the critical thinking skills of prospective teachers, it has been an interesting finding for this study that the scores from the critical thinking sub-dimension of the digital citizenship scale of prospective teachers at the beginning of the digital literacy course were high.

Another sub-problem of this study concerns the sub-dimension of digital skills. In this context, we observe the positive effects of the digital literacy course when we examine pre-test and post-test score differences of prospective teachers. Having special importance for digital citizens, digital skills require individuals to become aware of digital technologies used in their age and use these technologies effectively. Therefore, the ability of prospective teachers to effectively use digital technologies in education processes is also relevant to their digital skills. Prospective teachers acquiring digital skills, one of the 21 st-century skills, is important also for the students they will educate. Thus, it is important that they enhance their skills in this regard during their education in the faculties of education. Under another sub-problem of the study, pre-test and post-test score differences in the digital rights and responsibilities dimension were compared. It was found that the average score of prospective social sciences teachers in the digital rights and responsibilities dimension at the beginning of the digital literacy training were significantly $(\mathrm{P}<0.05 ; 0.01)$ different from their post-test average score. In this context, we can state that the training participants received positively differentiated their digital rights and 


\section{Impact of the Digital Literacy Courses Taken by the Prospective Social Studies Teachers by Distance Learning on Digital Citizenship Skill \\ Mithat Aydın, Türkan Çelik}

responsibilities skills. The youth, who use virtual environments very frequently, becoming aware of what their rights and responsibilities are matters in making them conscious citizens of digital environments, which will benefit them. In another sub-problem of the study, the dimension of digital participation, there was also a significant positive difference. In our time when the virtual environment is used frequently with the help of digital tools, it is known that it has become easier for individuals to participate in activities such as governing their countries, political decision-making processes, and forming public opinion. This action called political 'participation' was defined by Sezen (2000) as the ability of individuals to actively play a role in the making and application of certain decisions in the process of the formation of social order and the opportunity given to people for expressing their opinion. Hence, 'digital participation' is important for prospective social sciences teachers as they have the mission of helping students gain information that will function to make social life easier. Similarly, another sub-problem where a significant positive difference was found was the dimension of digital commerce. Nowadays, individuals can order and buy from their couch products from different cities, areas, or countries. In this context, in the digital environment, an intense commercial activity occurs. The skill to buy and sell properly and consciously in digital commerce, which makes commerce more comfortable for people, is important. In this context, prospective teachers having the skills to conduct commercial activities in digital environments has become a necessity of digital citizenship. However, an important factor in the digital commerce activities of individuals is how safe are the channels through which these activities are conducted. In this context, and similar to the previous dimension, research findings on the dimension of digital security, another necessity of digital citizenship, showed a significant difference. That the pre-test average score $(\overline{\mathrm{X}}: 17.5000)$ of prospective teachers were found to be significantly $(\mathrm{P}<0.05 ; 0.008)$ higher than their post-test average score $(\overline{\mathrm{X}}: 14.2000)$ shows that the resulting difference was significant but negative. In this context, it is a thought-provoking finding that the digital security pre-test scores of prospective teachers before they took the digital literacy course were significantly higher than their post-test scores. Indeed, nowadays, individuals prefer to conduct many activities such as communication, sharing special moments and their feelings, shopping, education, egovernment procedures, and others in digital environments. However, in recent times, the stealing of personal accounts, cyber attacks, and cyber fraud activities that emerged with the increase in commercial activities on the internet call attention to digital security skills. Such that, the leading problem among those experienced in digital channels is the problem of digital security. Problems experienced in these channels can discredit digital channels in citizens' eyes and may even cause them to suffer heavy traumas. When considering that digital security skills, one of the most important necessities of the digital world, refer to precautions individuals take to ensure the security of the networks and personal data when using technology and virtual environments (Ribble \& Bailey, 2007), it is thought that this result should be taken into account by institutions offering digital literacy training.

It is concluded that there was a significant positive difference between the digital citizenship skills pre-test and posttest scores of prospective teachers that took the digital literacy course with distance learning. This result shows that overall, the participants' digital citizenship skills benefitted from the digital literacy course that they took with distance learning. However, when the sub-problems of the study regarding the sub-dimensions of the digital citizenship scale are examined, it is observed that there was not any significant positive difference between the pre-test and post-test scores in 'digital communication', 'digital ethics', and 'critical thinking' skills. On the other hand, a positive significant difference was detected between scores from digital skills, digital participation, digital rights and responsibilities, and digital commerce sub-dimensions in the study. However, it was found that the difference that emerged in the research findings on the digital security sub-problem was significant but negative. Based on these results of the study, some suggestions are made below.

\section{Suggestions}

This study investigated the efficacy of the digital literacy course, offered to undergraduates in the faculty of education as part of the 'Digital Transformation in Higher Education Project' conducted with the cooperation of CHE and Anadolu University, on social sciences teachers. The university where this research was conducted is one of the pilot universities chosen for the digital transformation process. In suggestions of studies (Sezgin \& Karabacak, 2020) conducted in this manner, it is recommended that curriculum planners remain in coordination with competent universities in Turkey. It is suggested that an interactive model be formed, with which competent and technically capable universities are contacted as to the content of courses, how the courses are to be applied, and what path to follow outside the course. Moreover, the implementing universities should set up coordination offices for this issue, and academic and administrative personnel interested in the subject should be assigned to these offices. In this study, conducted by taking into account the primary need for teachers with digital skills in allowing the students of the 21 st century to receive a quality education, the suggestions below are made.

- Considering that the digital literacy training offered to prospective teachers with distance learning made an overall positive difference in their digital citizenship skills, it can be stated that similar training should be made more common. 
- It was found that the digital literacy training offered with distance learning did not make any positive difference in three dimensions of the study, namely 'digital communication', 'digital ethics', and 'critical thinking'. Based on this finding, it is suggested that emphasis should be laid on more functional subjects unknown to prospective teachers rather than on those with which they are thought to be familiar.

- Another important finding of the study is that there was a significant but negative difference between the pre-test and post-test scores in the digital security skills sub-problem. Therefore, it is suggested that institutions offering the digital literacy course with distance learning make changes to the curriculum regarding digital security and enrich this subject.

\section{References}

Akkoyunlu, B. \& Soylu, Y. (2010). Öğretmenlerin sayısal yetkinlikleri üzerine bir çalıșma. Türk Kütüphaneciliği, 24(4), 748-768. Retrieved from https://dergipark.org.tr/tr/pub/tk/issue/48858/622491.

Arcagök, S. (2020). Öğretmenlerin dijital vatandaşlığa yönelik algılarının incelenmesi, YYÜ Eğitim Fakültesi Dergisi (YYU Journal of Education Faculty), 17(1), 534-556. https://doi.org/10.33711/yyuefd.693832

Aslan, S. (2016). İlköğretim sosyal bilgiler ögretmen adaylarının dijital vatandaşlık davranışlarının bazı değişkenler açısından incelenmesi, (Fırat, Dicle, Siirt, Adıyaman Üniversiteleri Örneği). Yayınlanmamış Yüksek Lisans Tezi, Firat Üniversitesi Eğitim Bilimleri Enstitüsü, Elâzı̆̆. Retrieved from https://openaccess.firat.edu.tr/xmlui/bitstream/handle/11508/12388/445663.pdf?sequence=1\&isAllowed=y

Aydemir, M. (2019). Yenilenen sosyal bilgiler dersi öğretim programının dijital vatandaşlık ve alt boyutları açısından incelenmesi. Uluslararası Güncel Eğitim Araştırmaları Dergisi, 4 (2), 15-38. Retrieved from https://dergipark.org.tr/tr/pub/intjces/issue/43579/533510

Aydın, A. (2015). Dijital vatandaşlık. Türk Kütüphaneciliği 29(1), 142-146. Retrieved from http://www.tk.org.tr/index.php/TK/article/view/2530/2534

Bakır, E. (2016). Sınıf öğretmeni adaylarının dijital vatandaşlık seviyelerinin dijital vatandaşlık alt boyutlarına göre incelenmesi. Yayınlanmamış Yüksek Lisans Tezi, Karadeniz Teknik Üniversitesi Eğitim Bilimleri Enstitüsü. Retrieved from Trabzon. https://tez.yok.gov.tr/UlusalTezMerkezi/tezDetay.jsp?id=uq 8VoGZOzPk529Pwcju3g\&no=peHjRXIhJhgBLl K3-hACSA

Büyüköztürk, Ş., Kılıç Çakmak, E., Akgün, Ö.E., Karadeniz, Ş., \& Demirel, F., (2013). Bilimsel araştırma yöntemleri (14. Bask1). Ankara: Pegem Akademi Yayınevi.

Çakmak, Z. \& Aslan, S. (2018). Sosyal bilgiler öğretmen adaylarının dijital vatandaşlık davranışlarının bazı değişkenler açısından incelenmesi. Adlyaman Üniversitesi Ĕ̆itim Bilimleri Dergisi, 8(1), $72-99$. https://doi.org/10.17984/adyuebd.296203

Çubukcu, A. \& Bayzan, Ş. (2013). Türkiye'de dijital vatandaşlık algısı ve bu algıyı internetin bilinçli, güvenli ve etkin kullanımı ile artırma yöntemleri. Middle Eastern \& African Journal of Educational Research, 5, 148-174. Retrieved from https://www.guvenliweb.org.tr/dosya/73bDc.pdf

Dere, İ. \& Yavuzay, M. (2019). Sosyal bilgiler öğretmen adaylarının dijital vatandaşlık göstergelerinin incelenmesi, Manas Sosyal Araştırmalar Dergisi, 8(3), 2400-2414. https://doi.org/10.33206/mjss.537592

Elçi, A. C. \& Sarı, M. (2016). Bilişim teknolojileri ve yazılım dersi öğretim programına yönelik öğrenci görüşlerinin dijital vatandaşlık bağlamında incelenmesi, Ç. U. Sosyal Bilimler Enstitüsü Dergisi, 25 (3), 87-102. Retrieved from https://dergipark.org.tr/tr/pub/cusosbil/issue/32038/353253

Elçi, C. A. (2015). Bilişim teknolojileri ve yazılım dersi öğretim programına yönelik öğrenci görüşlerinin dijital vatandaşlık bağlamında incelenmesi, Yayınlanmamış Yüksek Lisans Tezi, Çukurova Üniversitesi Sosyal Bilimler Enstitüsü, Adana.

Erdoğan, E. \& Tonga, D. (2020). Middle school students and digital citizenship: is technology important for digital citizens in Turkey?, International Journal of Education Technology and Scientific Researches, 5 (11),194-227). Retrieved from https://files.eric.ed.gov/fulltext/ED605583.pdf

Eshet, Y. (2002). Digital literacy: a new terminology framework and its application to the design of meaningful technology-based learning environments. World Conference on Educational Multimedia, Hypermedia and Telecommunications (EDMEDIA), 493-498. Chesapeake, VA: AACE

Farmer, L. (2010) 21. Century Standarts for Information Literacy. Leadership, 39 (4), 20-22.

Fundalina (2020). 2020 Yll Global Dijital Raporu. Erşim Adresi: https://www.fundalina.com/2020-yili-global-dijitalraporu/ Erişim Tarihi: 02.08.2020.

Görmez, E. (2016). "Öğretmen adaylarının "dijital vatandaşlık ve alt boyutları" hakkındaki görüşleri (bir durum çalışmas1), Turkish Studies International Periodical for the Languages, Literature and History of Turkish or Turkic, 11(21), 125-144. Retrieved from https://app.trdizin.gov.tr/publication/paper/detail/TWpjeU5UVTNOdz09 
Görmez, E. (2017). İlkokul sosyal bilgiler programının dijital vatandaşlık ve alt boyutları açısından yeterliliği. International Journal of Social Science 2(60), 1-15. Retrieved from https://dergipark.org.tr/tr/pub/intjces/issue/43579/533510

Hague, C. \& Payton, S. (2010). Digital literacy across the curriculum. Futurelab Retrieved from https://www.researchgate.net/publication/292988382 Digital Literacy - New wine in old bottles

Jones Kavalier, B.R. \& Flannigan, S.L. (2006). Connecting the Digital Dots: Literacy of the 21 st Century. Educause Quarterly, 29(2), 8-10. https://www.learntechlib.org/p/103770/ ,Erişim tarihi: 08.08.2020.

Kaptan S. (1995). Bilimsel araştırma ve istatistik teknikleri. Ankara: Tekışık Web Ofset Tesisleri

Kara, T, Atasoy, E. (2019). Sosyal bilgiler öğretim programı ve ders kitaplarının (2018) dijital vatandaşlık kavramı ve alt boyutları bağlamında incelenmesi. Balıkesir Üniversitesi Sosyal Bilimler Enstitüsü Dergisi, 22 (41), 133-154. https://doi.org/10.31795/baunsobed.581917

Karaduman, H. \& Öztürk, C. (2014). Sosyal bilgiler dersinde dijital vatandaşlığa dayalı etkinliklerin öğrencilerin dijital vatandaşlık tutumlarına etkisi ve dijital vatandaşlık anlayışlarına yansımaları. Sosyal Bilgiler Eğitimi Araştırmalart Dergisi 5(1), 38-78. Retrieved from https://dergipark.org.tr/tr/pub/jsser/issue/19102/202728

Karaduman, H. (2011). 6. sinıf sosyal bilgiler dersinde dijital vatandaşlığa dayalı etkinliklerin ögrencilerin dijital ortamdaki tutumlarına etkisi ve ögrenme öğretme sürecine yansımaları. Yayımlanmamış Doktora Tezi, Marmara Üniversitesi, İstanbul. Retrieved from https://katalog.marmara.edu.tr/eyayin/tez/T0074563.pdf

Kaya, A. \& Kaya, B. (2014). Öğretmen Adaylarının Dijital Vatandaşlık Algısı. International Journal of Human Sciences, 11(2), 346-361. Retrieved from https://www.j-humansciences.com/ojs/index.php/IJHS/article/view/2917/1337

Kocadağ, T. (2012). Öğretmen adaylarının dijital vatandaşlık düzeylerinin belirlenmesi. Yayınlanmamış Yüksek Lisans Tezi, Karadeniz Teknik Üniversitesi Eğitim Bilimleri Enstitüsü Bilgisayar ve Öğretim Teknolojileri Eğitimi Anabilim Dalı, Trabzon.

Koçoğlu, A, Yanpar Yelken, T. \& Kanadlı, S. (2020). Ortaokul öğrencilerinin bilişim teknolojilerinden yararlanma düzeyleri ile toplumsal değerlere yönelik algıları arasındaki ilişkinin incelenmesi. Afyon Kocatepe Üniversitesi Sosyal Bilimler Dergisi, 22 (2), 399-417.

Kurt, A. (2013). Teknopedagojik eğitim modeli. I. Kabakçı Yurdakul (Editör). Ĕ̆itimde teknoloji Entegrasyonuna Kavramsal ve Kuramsal Bakış içinde (s. 3-37). Ankara: Anı Yayıncılık.

Kuş, Z., Güneş, E., Başarmak, U., \& Yakar, H. (2017). Development of a digital citizenship scale for youth: A validity and reliability study. Journal of Computer and Education Research, 5 (10), 298-316.

Milli Eğitim Bakanlığı [MEB] (2018). Sosyal bilgiler ögretim programı, Erişim adresi: http://mufredat.meb.gov.tr/Dosyalar/201812103847686SOSYAL $\% 20 \mathrm{~B} \% \mathrm{C} 4 \% \mathrm{~B} 0 \mathrm{LG} \% \mathrm{C} 4 \% \mathrm{~B} 0 \mathrm{LER} \% 20 \% \mathrm{C} 3 \%$ 96\%C4\%9ERET\%C4\%B0M\%20PROGRAMI\%20.pdf. Erişim tarihi: 16. 07. 2020 erişilmiştir.

Mossberger, K., Tolbert, C. \& S. McNeal, R. (2008). Digital citizenship: the internet, society, and participation. London, England: The MIT Press.

Orhan Göksün, D. \& Kurt, A., (2018). Öğretim teknolojilerinin temelleri, A. A., Kurt (Ed.), 21. yüzyıl ögrrenci ve öğretmen becerileri (s. 95-114). Ankara: Nobel Akademi Yayıncılık.

Öztürk, C. (2015). Sosyal bilgiler: toplumsal yaşama disiplinler arası bir bakış, C., Öztürk (Ed.), Sosyal bilgiler öğretimi, demokratik vatandaşlık eğitimi içinden (s. 1-31). Ankara: Pegem Akademi Yayınları.

Pilgrim, J. \& Matinez, E. E. (2013). Defining literacy in the 21 st century: a guideto terminology and skills. Texas Journal of Literacy, 1(1), 60-69. Retrieved from https://files.eric.ed.gov/fulltext/EJ1110822.pdf

Prensky, M. (2001). Digital natives, digital immigrants part 1. On the Horizon, 9(5), 1-6. Retrieved from https://www.marcprensky.com/writing/Prensky $\% 20 \% 20$ Digital $\% 20$ Natives, $\% 20$ Digital $\% 20$ Immigrants $\% 20$ \%20Part1.pdf

Ribble, M. \& Bailey, G. (2007). Digital citizenship in schools. Washington, DC: International Society for Technology in Education.

Ribble, M. (2011). Digital Citizenship in Schools (2nd ed.). Eugene, OR: International Society for Technology in Education (ISTE). https://www.iste.org/docs/excerpts/DIGCI2-excerpt.pdf. Erişim Tarihi: 16.07.2020

Sakallı, H. \& Çiftci, S. (2016). Sınıf öğretmeni adaylarının dijital vatandaşlık düzeyleri ile siber zorbalık eğilimleri arasındaki ilişkinin incelenmesi: Adnan Menderes Üniversitesi Örneği. Eğitim teknolojisi kuram ve uygulama, 6(2), 100-119. https://doi.org/10.17943/etku.97311

Sakallı, H. (2015). Sınıf öğretmeni adaylarının dijital vatandaşlık düzeyleri ile siber zorbalık eğilimleri arasındaki ilişkinin incelenmesi. Yayınlanmamış Yüksek Lisans Tezi, Adnan Menderes Üniversitesi Sosyal Bilimler Enstitüsü, Aydın. Retrieved from http://adudspace.adu.edu.tr:8080/xmlui/handle/11607/1498

Sezen, S. (2000). Seçim ve demokrasi, 2. Basım, Gündoğan Yayınları, Ankara.

Sezgin, A.A. \& Karabacak, Z. İ., (2020). Yükseköğretimde dijital dönüşüm ve dijital okuryazarlık dersine yönelik betimsel bir analiz, Anadolu Üniversitesi İletişim Bilimleri Fakültesi Uluslararası Hakemli Dergisi, 28 (1), 17 30. Retrieved from https://dergipark.org.tr/tr/pub/kurgu/issue/55448/718091

Som Vural, S. ve Kurt, A., A. (2017). Üniversite öğrencilerinin bakış açısıyla dijital vatandaşlık göstergelerinin incelenmesi. Eğitim teknolojisi kuram ve uygulama, 8(1), 60-80. https://doi.org/10.17943/etku.317713

Sönmez, V., \& Alacapınar, F. G. (2013). Örneklendirilmiş bilimsel araştırma yöntemleri. Anı Yayıncılık. 
Turan S. \& Karasu A. E. (2018). 2018 sosyal bilgiler öğretim programı'nın dijital vatandaşlık bağlamında incelenmesi. Eğitim ve Yeni Yaklaşımlar Dergisi, 1(1), 28-38. Retrieved from https://dergipark.org.tr/tr/pub/jena/issue/42984/519671

Ünal, D. P. (2017). Bir öğretim programındaki dijital vatandaşlık öğeleri ve ortaöğretim öğrencilerinin dijital vatandaşlık ögelerine sahip olma durumları. Karaelmas Ĕ̆itim Bilimleri Dergisi, 5 (2), 180-195.

Uzun, H. (2019). 21. yüzyıl becerisiolarak vatandaşlık ve kültür, E. Ömeroğlu \& H. Şahin (Ed.).21. Yüzyıl çocuklarının eğitimi: 6 C modeli içinde (s. 61-86), Ankara: Eğiten Kitap Yayıncılık.

Yeşiltaş, E. \& Sönmez, Ö. F. (2009). Sosyal bilgiler öğretiminde bilgisayar kullanımı ve bilgisayar tabanlı materyal geliştirme. R. Turan ve diğ. (Ed.), Sosyal bilgiler ögretiminde yeni yaklaşımlar I, 387-415, Ankara: Pegem Akademi 